\title{
Naringenin Inhibits the Growth and Stimulates the Lignification of Soybean Root
}

\author{
Graciene de Souza Bido, Maria de Lourdes Lucio Ferrarese, Rogério Marchiosi and \\ Osvaldo Ferrarese-Filho* \\ Laboratório de Bioquímica Vegetal; Universidade Estadual de Maringá; Av. Colombo, 5790; 87020-900; \\ Maringá - PR - Brasil
}

\begin{abstract}
The flavanone naringenin, an intermediate in flavonoid biosynthesis, was tested for its effect on root growth, phenylalanine ammonia-lyase (PAL) and peroxidase (POD) activities, as well as phenolic compounds and lignin contents in soybean (Glycine max L. Merrill) seedlings. Three-day-old seedlings were cultivated in half-strength Hoagland nutrient solution ( $\mathrm{pH}$ 6.0), with or without 0.1 to $0.4 \mathrm{mM}$ naringenin in a growth chamber $\left(25^{\circ} \mathrm{C}, 12-\mathrm{h}\right.$

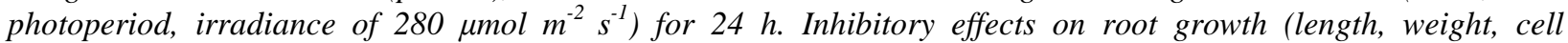
viability), PAL and soluble POD activities were detected after naringenin treatments. These effects were associated with stimulatory activity of the cell wall-bound POD followed by an increase in the lignin contents, suggesting that naringenin-induced inhibition in soybean roots could be due to the lignification process.
\end{abstract}

Key words: Allelopathy, lignin, flavonoid, peroxidase, phenylalanine ammonia-lyase, root growth

\section{INTRODUCTION}

For years, it has been known that plants release organic compounds into the environment from their aerial or sub-aerial parts as exudates, volatiles, and/or decomposition residues. These compounds may accumulate in the soil environment and affect the growth and development of neighboring plants, an interaction called allelopathy (Weir et al., 2004).

The presence of flavonoids, a class of secondary plant metabolic compounds, in the soil may have arisen from root exudation or dead leaves. When plant leaves drop and decay, flavonoids entering the soil may directly inhibit seed germination, or cause death or growth inhibition of roots or seedlings of other competing plant species (Onyilagha and Grotewold, 2004). Flavonoid allelochemicals include chalcones, dihydrochalcones, dihydroflavonols, isoflavonols, flavonols and flavanones (Iwashima, 2003). Flavonoids, including naringenin, are found in the soils in concentrations varying from 0.01 to 0.1 $\mathrm{mM}$ (Macias, 1995). Although flavonoids are frequently implicated in allelopathic reactions (Levizou et al., 2004; Weir et al., 2004; Taylor and Grotewold, 2005), their roles and mode of action is not fully understood. For example, (-)-catechin, exuded from the roots of Centaurea maculosa, induces oxidation and cellular death in the roots of Centaurea diffusa and Arabidopsis thaliana by producing reactive oxygen species (ROS) as well as triggering genes that kill the cells (Bais et al., 2003). Quercetin decreases respiration in isolated soybean hypocotyl mitochondria probably by interfering with electron transport and possibly by

\footnotetext{
* Author for correspondence: oferrarese@uem.br
} 
uncoupling oxidative phosphorylation (Takahashi et al., 1998). The growth of wild-type Arabidopsis plants on naringenin leads to a reduction in root growth and gravitropism, similar to the effects of synthetic auxin transport inhibitors (Brown et al., 2001).

Naringenin, which occupies a central position as the primary $\mathrm{C}_{15}$ intermediate in the flavonoid biosynthesis pathway, has been reported to suppress the growth of annual plant species, such as Spinacia oleracea, Lactuca sativa, Raphanus sativus, Lycopersicum esculentum, Daucus carota (Chen et al., 2004) and soybean (Colpas et al., 2003). Moreover, naringenin inhibits the activity of the key enzyme of the phenylpropanoid pathway, 4-coumarate: CoA ligase (4-CL, EC 6.2.1.12), suppresses the growth and reduces the lignin content in gramineous plants, such as Zea mays, Oryza sativa and Echinochloa oryzicola (Deng et al., 2004).

The phenylpropanoid pathway is one of the most important metabolic pathways since it is involved in the synthesis of phenolic compounds, as well as a wide range of secondary products in the plants, including lignin. This is the main structural component of secondarily thickened plant cell walls. Lignin imparts mechanical support and efficient conduction of water and solutes over long distances within the vascular systems. Structurally, it is a heteropolymer of hydroxylated and methoxylated phenylpropane units, derived from the oxidative polymerization of different hydroxycinnamyl alcohols ( $p$-coumaryl, coniferyl and sinapyl) connected by labile ether bonds and/or resistant carbon-carbon linkages (Boerjan et al., 2003). Phenylalanine ammonia-lyase (PAL) is the first rate-limiting enzyme of the phenylpropanoid pathway leading to the synthesis of the phenolic acids and, later, monolignols. Peroxidase (POD) within the cell wall, in the bound state, has been shown to be associated with monolignol polymerization and, therefore, lignin synthesis (Passardi et al., 2005).

Although the effects of naringenin on growth and lignin content in some species have been studied (Deng et al., 2004), no reports on the effects of exogenous naringenin on lignification of soybean roots are available thus far. Since lignification is essential for plant growth, the aim of the current research has been to analyze how exogenously supplied naringenin affects PAL and POD activities, phenolic compound and lignin contents and root growth of soybean seedlings.

\section{MATERIALS AND METHODS}

\section{General procedures}

Soybean (Glycine max cv. BRS-184) seeds, surface-sterilized with $2 \%$ sodium hypochlorite for $5 \mathrm{~min}$ and rinsed extensively with deionized water, were dark-germinated $\left(\right.$ at $25^{\circ} \mathrm{C}$ ) on three sheets of moistened filter paper. Twenty-five 3-days-old seedlings of uniform size were supported on an adjustable acrylic plate and transferred into a glass container $(10 \times 16 \mathrm{~cm})$ filled with $200 \mathrm{ml}$ of halfstrength Hoagland's solution $(\mathrm{pH}$ 6.0), with or without 0.1 to $0.4 \mathrm{mM}$ naringenin. The container was kept in a growth chamber $\left(25^{\circ} \mathrm{C}, 12-\mathrm{h}\right.$ photoperiod, irradiance of $280 \mu \mathrm{mol} \mathrm{m} \mathrm{m}^{-2} \mathrm{~s}^{-1}$ ). The roots were measured at the beginning and end of the experiments $(24 \mathrm{~h})$. The fresh root weight was determined immediately after incubation and the dry weight was estimated after oven-drying at $80^{\circ} \mathrm{C}$ until constant weight. Naringenin was purchased from Sigma Chemical Co (St Louis, USA), and all other reagents used were of the purest grade available or chromatographic grade.

\section{Cell viability}

After incubation, all the seedlings were removed to determine the loss of cell viability by using the Evans blue staining spectrophotometric assay (Baker and Mock, 1994) with modifications. The freshly harvested roots treated or untreated with naringenin were incubated for $15 \mathrm{~min}$ with $30 \mathrm{ml}$ of $0.25 \%$ Evans blue solution. Then, the roots were washed with distilled water for $30 \mathrm{~min}$ to remove the excess and unbound dye. Excised root tips $(3 \mathrm{~cm})$ were soaked in $3 \mathrm{ml}$ of $N, N-$ dimethylformamide for $50 \mathrm{~min}$ at room temperature to solubilize the dye bound to dead cells. The absorbance of released Evans blue was measured spectrophotometrically at $600 \mathrm{~nm}$, using deionized water as a blank. The loss of cell viability was expressed as absorbance of treated roots in relation to untreated roots (control).

\section{Enzymatic assays}

After incubation, all treated or untreated seedling roots were detached and enzymes were extracted. Phenylalanine ammonia-lyase (PAL) was extracted as described by Ferrarese et al. (2000). Fresh roots $(2 \mathrm{~g})$ were ground at $4^{\circ} \mathrm{C}$ in $0.1 \mathrm{M}$ sodium borate buffer ( $\mathrm{pH} 8.8$ ). Homogenates were centrifuged $(2200 \mathrm{~g}, 15 \mathrm{~min})$ and the supernatant was used as the enzyme preparation. The reaction 
mixture ( $1 \mathrm{ml}$ of sodium borate buffer $0.1 \mathrm{mM}, \mathrm{pH}$ 8.7 , and $0.25 \mathrm{ml}$ of enzyme extract) was incubated at $40^{\circ} \mathrm{C}$ for $5 \mathrm{~min}$ for the PAL activity assay. An amount of $0.3 \mathrm{ml}$ of $0.15 \mathrm{M}$ L-phenylalanine was added to start the reaction, which was stopped after $1 \mathrm{~h}$ of incubation by the addition of $50 \mu \mathrm{l}$ of 5 $\mathrm{N} \mathrm{HCl}$. Samples were filtered through a $0.45 \mu \mathrm{m}$ disposable syringe filter and analyzed $(20 \mu \mathrm{l})$ with a Shimadzu ${ }^{\circledR}$ Liquid Chromatograph (Tokyo, Japan) equipped with an LC-10AD pump, a Rheodyne ${ }^{\circledR}$ injector, an SPD-10A UV detector, a CBM-101 Communications Bus Module, and a Class-CR10 workstation system. A reversed-phase Shimpack $^{\circledR}$ GLC-ODS (M) column $(150 \times 4.6$ $\mathrm{mm}, 5 \mu \mathrm{m}$ ) was used at room temperature, with an equivalent pre-column $(10 \times 4.6 \mathrm{~mm})$. The mobile phase was methanol:water $(70: 30)$ with a flow rate of $0.5 \mathrm{ml} \mathrm{min}$. . Absorption was measured at 275 $\mathrm{nm}$. Data collection and integration were performed with Class-CR10 software (Shimadzu ${ }^{\circledR}$, Tokyo, Japan). $t$-Cinnamate, the product of PAL, was identified by comparing its retention time with standard values. Parallel controls without Lphenylalanine or with $t$-cinnamate (added as an internal standard in the reaction mixture) were performed as described elsewhere (Ferrarese et al., 2000). PAL activity was expressed as $\mu \mathrm{mol} t$ cinnamate $\mathrm{h}^{-1} \mathrm{~g}^{-1}$ fresh weight.

Peroxidase (POD) was extracted from fresh roots $(0.5 \mathrm{~g})$ with $67 \mathrm{mM}$ phosphate buffer $(5 \mathrm{ml}, \mathrm{pH}$ 7.0). The extract was centrifuged ( $2200 \mathrm{~g}, 5 \mathrm{~min}$, $4^{\circ} \mathrm{C}$ ), and the supernatant was used to determine the activity of soluble POD. For cell wall-bound POD isolation, the pellet was washed with deionized water until no soluble POD activity was detected in the supernatant. The pellet was then incubated in $1 \mathrm{M} \mathrm{NaCl}\left(2 \mathrm{ml}, 1 \mathrm{~h}, 4^{\circ} \mathrm{C}\right)$, and the homogenate was centrifuged $(2200 \mathrm{~g}, 5 \mathrm{~min})$. The supernatant contained the cell wall-(ionically)bound POD. Guaiacol-dependent activities of the soluble and cell wall-bound POD were determined according to Cakmak and Horst (1991), with slight modifications. The reaction mixture $(3 \mathrm{ml})$ contained $25 \mathrm{mM}$ sodium phosphate buffer, $\mathrm{pH}$ $6.8,2.58 \mathrm{mM}$ guaiacol and $10 \mathrm{mM} \mathrm{H}_{2} \mathrm{O}_{2}$. The reaction was started by adding the enzyme extract into the phosphate buffer. The guaiacol oxidation was followed for $5 \mathrm{~min}$ at $470 \mathrm{~nm}$, and enzyme activity was calculated from the extinction coefficient $\left(25.5 \mathrm{mM}^{-1} \mathrm{~cm}^{-1}\right)$ for tetraguaiacol. The blank consisted of a reaction mixture without enzyme extract and its absorbance was subtracted from the mixture with enzyme extract. POD activities were expressed as $\mu \mathrm{mol}$ tetraguaiacol $\min ^{-1} \mathrm{~g}^{-1}$ fresh weight.

\section{Phenolic compound quantification}

Dry roots $(0.25 \mathrm{~g})$ were boiled for $30 \mathrm{~min}$ in $5 \mathrm{ml}$ of $2 \mathrm{~N} \mathrm{HCl}$. After cooling, the homogenate was filtered through a Whatman ${ }^{\circledR}$ paper and the filtrate used to determine the total phenolic compound content. Samples $(5 \mathrm{ml})$ were mixed with $0.75 \mathrm{ml}$ of $1.9 \mathrm{M} \mathrm{Na}_{2} \mathrm{CO}_{3}$ plus $0.25 \mathrm{ml}$ of Folin-Ciocalteau phenol reagent. This mixture was kept in the dark at room temperature $\left(23-25^{\circ} \mathrm{C}\right)$ for one hour before its absorption was read at $750 \mathrm{~nm}$ (Herrig et al., 2002). Ferulic acid was used as the standard. Results were expressed as mg total phenolic compound content $\mathrm{g}^{-1}$ dry weight. Hydroxybenzoic (gallic, protocatechuic and $p$-hydroxybenzoic) and hydroxycinnamic (caffeic, $p$-coumaric, ferulic and sinapic) acids were determined with a high performance liquid chromatography (HPLC) system (Shimadzu ${ }^{\circledR}$ LC10AD, Tokyo, Japan), as described earlier. The mobile phase was methanol: acetic acid (30:4) with a flow rate of $0.8 \mathrm{ml} \mathrm{min}^{-1}$. Hydroxybenzoic and hydroxycinnamic acids were identified, at $254 \mathrm{~nm}$, by comparing their retention times with standards values (Ramakrishina et al., 1989). Results were expressed as $\mathrm{mg} \mathrm{g}^{-1}$ dry weight.

\section{Lignin Quantification}

Dry roots $(0.3 \mathrm{~g})$ were homogenized in $50 \mathrm{mM}$ potassium phosphate buffer $(7 \mathrm{ml}, \mathrm{pH} 7.0)$ with mortar and pestle, and transferred to a centrifuge tube (Ferrarese et al., 2002). The pellet was centrifuged (1400 $\mathrm{g}, 4 \mathrm{~min})$ and washed by successive stirring and centrifugation, as follows: twice with phosphate buffer $\mathrm{pH} 7.0(7 \mathrm{ml})$; three times with $1 \%$ (v/v) Triton X-100 in $\mathrm{pH} 7.0$ buffer (7 ml); twice with $1 \mathrm{M} \mathrm{NaCl}$ in $\mathrm{pH} 7.0$ buffer (7 $\mathrm{ml})$; twice with distilled water $(7 \mathrm{ml})$ and twice with acetone $(5 \mathrm{ml})$. Pellet was left overnight in a desiccator for drying. Pellet was finally dried in an oven $\left(24 \mathrm{~h}, 60^{\circ} \mathrm{C}\right)$. Cooled down in a vacuum desiccator, the dry matter obtained was defined as the protein-free cell wall fraction. Further, dry protein-free tissue $(0.1 \mathrm{~g})$ was placed into a screwcap centrifuge tube containing the reaction mixture $(1.2 \mathrm{ml}$ of thioglycolic acid plus $6 \mathrm{ml}$ of $2 \mathrm{M} \mathrm{HCl}$ ) and heated $\left(95^{\circ} \mathrm{C}, 4 \mathrm{~h}\right)$. After cooling at room temperature, the sample was centrifuged $(1400 \mathrm{~g}$, $5 \mathrm{~min}$ ) and the supernatant decanted. The pellet 
was washed three times with distilled water $(7 \mathrm{ml})$, and the product extracted by shaking $\left(30^{\circ} \mathrm{C}, 18 \mathrm{~h}\right.$, 115 oscillations $\left.\mathrm{min}^{-1}\right)$ in $0.5 \mathrm{M} \mathrm{NaOH}(6 \mathrm{ml})$. After centrifugation (1400 $g, 5 \mathrm{~min})$, the supernatant was stored and mixed with supernatant obtained from a second pellet washed with $0.5 \mathrm{M}$ $\mathrm{NaOH}(3 \mathrm{ml})$. The combined alkali extracts were acidified with concentrated $\mathrm{HCl}(1.8 \mathrm{ml})$. The lignothioglycolic acid formed after $4 \mathrm{~h}$ at $0^{\circ} \mathrm{C}$ was recovered by centrifugation $(1400 \mathrm{~g}, 5 \mathrm{~min})$ and washed twice in distilled water $(7 \mathrm{ml})$. The pellet was dried at $60^{\circ} \mathrm{C}$, dissolved in $0.5 \mathrm{M} \mathrm{NaOH}$, and diluted to yield an appropriate absorbance for spectrophotometric determination at $280 \mathrm{~nm}$.

\section{Statistical design}

The experimental design was completely randomized and each plot was represented by one glass container with 25 seedlings. Data are expressed as the mean of three or four independent experiments \pm SE. The data were processed using GraphPad Prism ${ }^{\circledR}$ package (GraphPad Software Inc., USA, 1995). The means were separated using one-way analysis of variance, and deviation from control was checked by post hoc Dunnett tests at $P$ $\leq 0.05$.

\section{RESULTS}

To evaluate the effects of naringenin on root growth, soybean seedlings were grown during short-term exposure $(24 \mathrm{~h})$ in nutrient solution containing 0.1 to $0.4 \mathrm{mM}$ flavonoid. Table 1 showed that root lengths and root fresh and dry weights decreased with increasing concentrations. After 0.1 to $0.4 \mathrm{mM}$ naringenin treatments, the mean total root lengths were 34.7 to $90.8 \%$ less than control. A similar trend was also evident in root fresh and dry weights, which significantly decreased after 0.1 to $0.4 \mathrm{mM}$ naringenin treatments: 19.5 to $33.8 \%$ for fresh and 25.5 to $31.7 \%$ for dry weights.

Fig. 1 shows the effects of naringenin on cell viability of roots. A significant level of Evans blue uptake was determined after both $0.3 \mathrm{mM}$ and 0.4 $\mathrm{mM}$ of naringenin treatment in the roots, representing 4.3 and 6.7 -fold, respectively, of that in control roots. No significant changes were observed in cell viability after 0.1 and $0.2 \mathrm{mM}$ naringenin exposures.

Naringenin-affected PAL activities were significantly different from controls (Fig. 2). The flavonoid decreased the enzymatic activities from 29 to $34 \%$ after 0.1 to $0.4 \mathrm{mM}$ treatments. In addition to these earlier findings, subsequent experiments showed the effects of naringenin on the total phenolic compounds of soybean roots. As seen in Fig. 3, total phenolic content was significantly reduced $7 \%$ (at $0.4 \mathrm{mM}$ ) when compared to untreated roots.

The HPLC quantification of hydroxybenzoic (gallic, protocatechuic and $p$-hydroxybenzoic) and hydroxycinnamic (caffeic, $p$-coumaric, ferulic and sinapic) acids in soybean roots grown in nutrient solution with naringenin can be seen in Table 2 . The results revealed that the protocatechuic, caffeic, $p$-coumaric, ferulic and sinapic acids were not detected in soybean roots. No appreciable change was observed in the gallic acid content after naringenin exposure, when compared to control conditions. On the other hand, $p$ hydroxybenzoic acid content increased up to 5fold after 0.1 to $0.4 \mathrm{mM}$ naringenin treatments.

Table 1 - Changes in the root length, root fresh weight and root dry weight of soybean seedlings treated for $24 \mathrm{~h}$ with naringenin.

\begin{tabular}{lcccccc}
\hline $\begin{array}{l}\text { Naringenin } \\
(\mathbf{m M})\end{array}$ & $\begin{array}{c}\text { Root length } \\
(\mathbf{c m})\end{array}$ & $\boldsymbol{\%}$ & $\begin{array}{c}\text { Fresh weight } \\
(\mathbf{g})\end{array}$ & $\boldsymbol{\%}$ & $\begin{array}{c}\text { Dry weight } \\
(\mathbf{g})\end{array}$ & $\boldsymbol{\%}$ \\
\hline 0 & $3.08 \pm 0.134$ & & $2.21 \pm 0.036$ & & $0.145 \pm 0.005$ & \\
0.1 & $2.01 \pm 0.053^{*}$ & 34.7 & $1.78 \pm 0.032 *$ & 19.5 & $0.108 \pm 0.001 *$ & 25.5 \\
0.2 & $2.22 \pm 0.082^{*}$ & 27.9 & $1.60 \pm 0.019 *$ & 27.9 & $0.097 \pm 0.002^{*}$ & 33.1 \\
0.3 & $1.23 \pm 0.100^{*}$ & 60.0 & $1.85 \pm 0.097 *$ & 16.5 & $0.129 \pm 0.001 *$ & 11.0 \\
0.4 & $0.28 \pm 0.034^{*}$ & 90.8 & $1.47 \pm 0.022^{*}$ & 33.8 & $0.099 \pm 0.003 *$ & 31.7 \\
\hline
\end{tabular}

Means $(N=3 \pm$ SE) significantly $(P \leq 0.05)$ smaller than the control experiment (Dunnett's multiple comparison test) are marked *. The symbol \% represents inhibition of statistically significant means in comparison to control $(0 \mathrm{mM})$. 


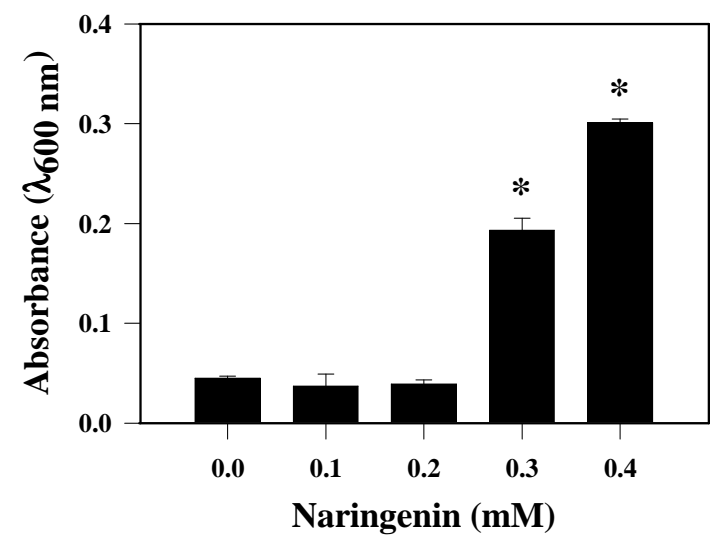

Figure 1 - Loss of cell viability in roots of soybean seedlings treated with naringenin. Mean values \pm SE from three independent experiments with 25 seedlings for each determination are shown. *Significant at $P \leq 0.05$ level as compared with the control seedlings.

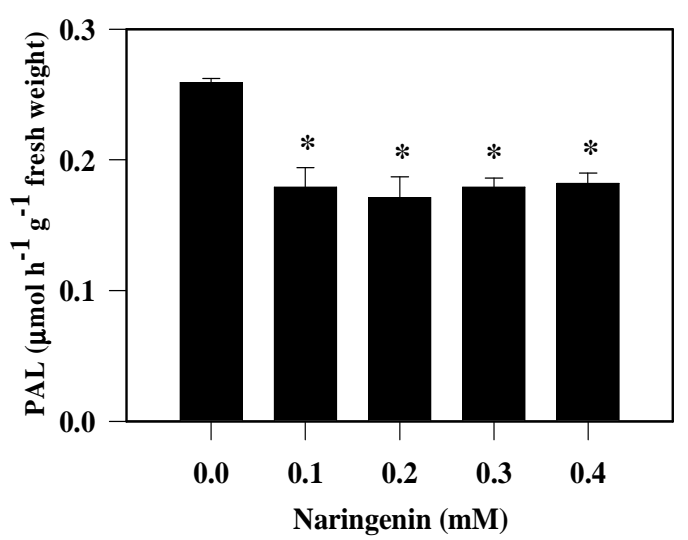

Figure 2 - Effects of naringenin on PAL (phenylalanine ammonia-lyase) activities. Mean values \pm SE from three independent experiments with 25 seedlings for each determination are shown. *Significant at $P \leq 0.05$ level as compared with the control seedlings.

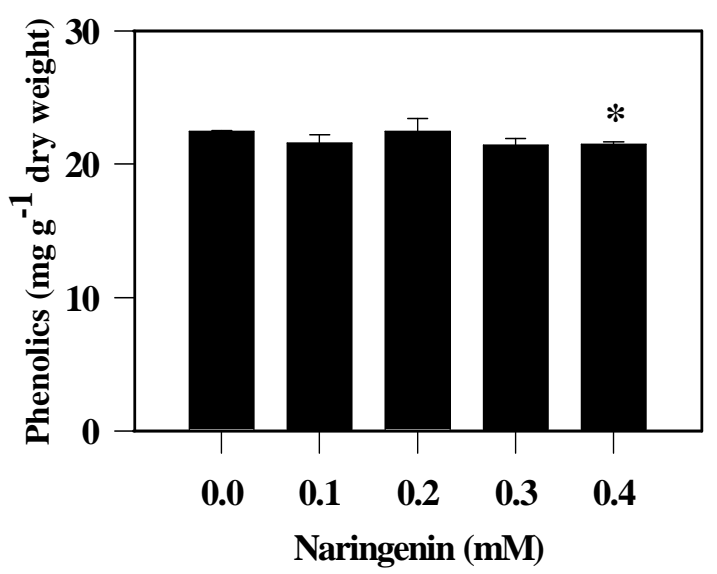

Figure 3 - Effects of naringenin on total phenolic compound content. Mean values \pm SE from three independent experiments with 25 seedlings for each determination are shown. *Significant at $P \leq 0.05$ level as compared with the control seedlings. 


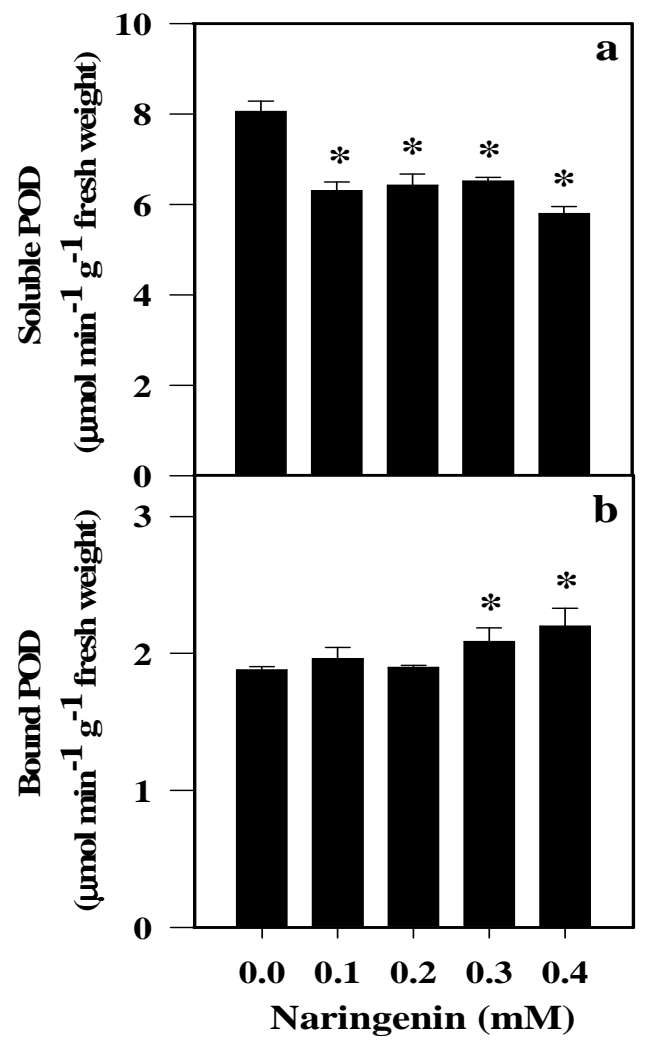

Figure 4 - Effects of naringenin on soluble (a) and cell wall-bound (b) peroxidases (POD). Mean values \pm SE from four independent experiments with 25 seedlings for each determination are shown. *Significant at $\mathrm{P} \leq 0.05$ level as compared with the control seedlings.

Table 2 - Changes in the phenolic acids content of soybean seedlings treated for $24 \mathrm{~h}$ with naringenin.

\begin{tabular}{cccccccc}
\hline $\begin{array}{c}\text { Naringenin } \\
(\mathbf{m M})\end{array}$ & \multicolumn{9}{c}{$\begin{array}{c}\text { Phenolic acid } \\
\left(\mathbf{m g} \mathbf{g}^{-1} \mathbf{d r y} \text { weight }\right)\end{array}$} \\
\cline { 2 - 8 } & gallic acid & $\begin{array}{c}\text { protocatechuic } \\
\text { acid }\end{array}$ & $\begin{array}{c}\boldsymbol{p} \text {-hydroxybenzoic } \\
\text { acid }\end{array}$ & $\begin{array}{c}\text { caffeic } \\
\text { acid }\end{array}$ & $\begin{array}{c}\boldsymbol{p} \text {-coumaric } \\
\text { acid }\end{array}$ & $\begin{array}{c}\text { ferulic } \\
\text { acid }\end{array}$ & $\begin{array}{c}\text { sinapic } \\
\text { acid }\end{array}$ \\
\hline 0 & $1.543 \pm 0.112$ & nd & $0.051 \pm 0.004$ & nd & nd & nd & nd \\
0.1 & $2.043 \pm 0.282^{\text {ns }}$ & nd & $0.206 \pm 0.012^{*}$ & nd & nd & nd & nd \\
0.2 & $2.247 \pm 0.662^{\text {ns }}$ & nd & $0.212 \pm 0.017^{*}$ & nd & nd & nd & nd \\
0.3 & $1.718 \pm 0.780^{\text {ns }}$ & nd & $0.245 \pm 0.020^{*}$ & nd & nd & nd & nd \\
0.4 & $1.736 \pm 0.178^{\text {ns }}$ & nd & $0.254 \pm 0.036^{*}$ & nd & nd & nd & nd \\
\hline
\end{tabular}

Means $(N=3 \pm$ SE) significantly $(P \leq 0.05)$ larger than the control experiment (Dunnett's multiple comparison test) are marked *. $n s=$ not significant. $\mathrm{nd}=$ not detected.

Naringenin decreased soluble POD activities around $22 \%$ regardless of its concentration, when compared to control (Fig. 4a). By contrast, cell wall-bound POD activities were significantly increased $10 \%$ (at $0.3 \mathrm{mM}$ ) and $17 \%$ (at $0.4 \mathrm{mM}$ ), when compared to control conditions (Fig. 4b). No significant differences in the enzymatic activities between the untreated and 0.1 or $0.2 \mathrm{mM}$ naringenin-treated roots were recorded. Finally, naringenin-affected lignin contents were significantly different from controls (Fig. 5). Data revealed that the lignin content increased from 2 to 3.5-fold after 0.1 to $0.4 \mathrm{mM}$ naringenin treatments. 


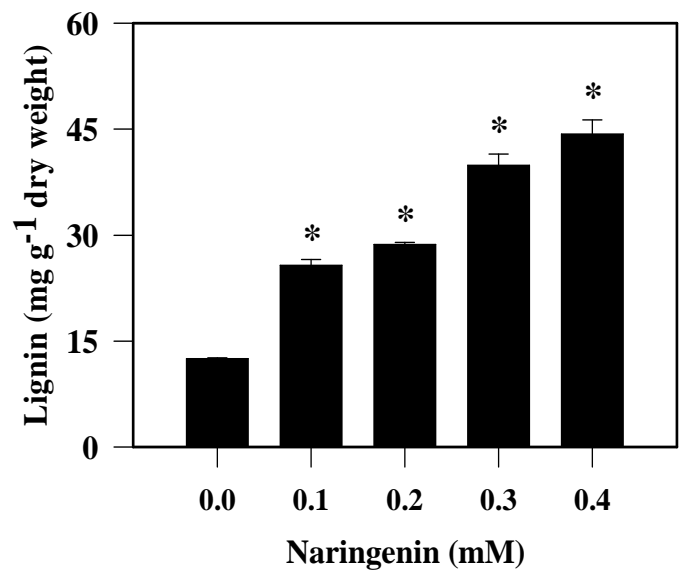

Figure 5 - Effects of naringenin on lignin contents. Mean values \pm SE from three independent experiments with 25 seedlings for each determination are shown. *Significant at $\mathrm{P} \leq$ 0.05 level as compared with the control seedlings.

\section{DISCUSSION}

Studies using $0.1 \mathrm{mM}$ naringenin applied in hydroponic cultures have shown root growth inhibition of different plant species (Chen et al., 2004). Naringenin inhibited (from 6.4 to $71.5 \%$ of control) root fresh weight of annual plants in ascending order: Oryza sativa $<$ Cucumis sativus < Glycine max < Brassica oleracea < Spinacia oleracea $<$ Lactuca sativa $<$ Raphanus sativus < Zea mays < Daucus carota < Lycopersicum esculentum. The results reported here showed naringenin effects from 0.1 to $0.4 \mathrm{mM}$. Since naringenin reduced the soybean root growth and fresh and dry weights (Table 1), its susceptibility was indicated and its role as an allelochemical was reinforced. In agreement with this, significant loss of cell viability was observed after 0.3 and $0.4 \mathrm{mM}$ naringenin treatments (Fig. 1).

Inhibitory effects of naringenin on growth and lignin content in some plant species have been reported (Deng et al., 2004). At $0.1 \mathrm{mM}$, naringenin suppressed the growth of maize, rice and early watergrass, and inhibited the activity of 4-coumarate:CoA ligase (4-CL), a key enzyme involved in the monolignol synthesis within the phenylpropanoid pathway. By contrast, the main fact revealed in the present study is that naringenin not only significantly reduced the root growth (length and weight) of soybean seedlings (Table 1), but also significantly increased root lignification (Fig. 5). The fact that naringenin stimulated lignin production in soybean roots was of particular interest. Reduction in growing roots has been considered one of the first effects of allelochemicals and, in some cases it is associated with premature lignification of the cell walls (Sánchez et al., 1996; dos Santos et al., 2004). To strengthen this assumption, some aspects related to the action of naringenin and phenylpropanoid pathway metabolism are discussed as below.

In the phenylpropanoid pathway, phenolic metabolites such as $p$-coumaric, caffeic, ferulic, 5hydroxyferulic and sinapic acids are produced from cinnamic acid, the product of the PAL reaction. Conversions of these cinnamic acid derivatives in their corresponding CoA esters are followed by the production of hydroxycinnamyl alcohols and, further, lignin. PAL catalyzes the first committed step of the phenylpropanoid biosynthetic pathway, i.e., the deamination of phenylalanine producing cinnamic acid.

Plants possess two groups of PODs: soluble and cell wall-bound. The first, localized in apoplastic space and in vacuoles, catalyzes most of peroxidative reactions, while the second catalyzes the last reaction of the metabolic pathway by oxidative polymerization of hydroxycinnamyl alcohols ( $p$-coumaryl, coniferyl and sinapyl), by using $\mathrm{H}_{2} \mathrm{O}_{2}$ as a substrate (Boerjan et al., 2003; Veitch, 2004; Passardi et al., 2005).

In general, the production of phenolic metabolites has been often observed when levels of phenylpropanoid pathway intermediates or end products are artificially increased. For example, stress caused by the addition of phenolic 
allelochemicals (ferulic and vanillic acids) in soybean stimulates cell wall bound-POD, and the accumulation of phenolic compounds and lignin (Herrig et al., 2002; dos Santos et al., 2004). However, inhibition of the soybean root growth (Table 1) after naringenin treatment has been related to reductions on the PAL activities (Fig. 2). There was at least some evidence supporting these results, i.e., an induced PAL of rice seedlings was sensitive to in vitro inhibition by naringenin and other phenylpropanoid intermediates (Sarma and Sharma, 1999). Since naringenin reduced (29 to $34 \%$ ) PAL activity, a decreased production of phenolic metabolites within the phenylpropanoid pathway might be expected. In fact, results showed that a significant reduction in total phenolics (measured colorimetrically) was recorded at 0.4 $\mathrm{mM}$ naringenin treatment (Fig. 3). In addition, hydroxycinnamic ( $p$-coumaric, caffeic, ferulic and sinapic) acids (measured by HPLC) were not detected in soybean roots (Table 2), suggesting that these compounds were further incorporated in lignin (Fig. 5) by the cell wall-bound POD (Fig. 4b).

Naringenin inhibited the soluble POD activities (Fig. 4a). The simplest explanation to evaluate the inhibitory mechanism of naringenin on soluble POD could be the fact that flavonoids chelate the metal ions, particularly copper and iron. In fact, flavonoids are known to chelate the metal ions at the 3',4'-dihydroxy positions in the B rings, at the 3-hydroxy, 4-keto group and at the 5-hydroxy (A ring), 4-keto group (Rice-Evans et al., 1997). POD contains an iron (III) protoporphyrin IX (protohemin) prosthetic group located at the active site. This metal center is essential for the catalytic activity of the enzyme involving exchanges of electrons and protons (Veitch, 2004). Then, the metal-chelating ability of the naringenin may possibly disturb the action of POD by reducing its activity. Soluble POD is often regarded as an antioxidant enzyme that protects cells from the destructive influence of $\mathrm{H}_{2} \mathrm{O}_{2}$ and derived oxygen radicals (ROS). However, if the capacity of the cells to scavenger oxygen radicals is reduced due inhibition of soluble POD by naringenin (Fig. 4a), the remaining $\mathrm{H}_{2} \mathrm{O}_{2}$ may be able to affect the membrane integrity, leaving the plant vulnerable to oxidative damage. Considerable loss in the cell viability (Fig. 1) corroborated this assumption.

As previously noted, PAL regulates the production of hydroxycinnamic acids, which are converted in monolignols that are later polymerized by cell wall-bound POD reactions to complete the lignification. This process requires oxidative coupling and is dependent on $\mathrm{H}_{2} \mathrm{O}_{2}$ (Boerjan et al., 2003). This relatively stable form of ROS may be accumulated due to inhibition of soluble POD by naringenin (Fig. 4a), as described earlier. Furthermore, an oxidative cycle of cell wall-bound POD has been proposed as a catalytic system for the supply of $\mathrm{H}_{2} \mathrm{O}_{2}$ for lignification (Passardi et al., 2005). Another interesting possibility is that the flavonoid may be directly involved in the production of ROS by means of an autooxidation reaction. Although naringenin autooxidation has not been related in soybean, it is known that quercetin autooxidation generates actived oxygen $\left(\mathrm{O}_{2}^{-}\right)$, which reacts with $\mathrm{H}_{2} \mathrm{O}$ by producing $\mathrm{H}_{2} \mathrm{O}_{2}$ (Pourcel et al., 2006). Moreover, in susceptible species, the flavonoid allelochemical (-)-catechin triggers a wave of ROS that leads to the death of the root system (Bais et al., 2003). As observed here, increased activities of cell wall-bound POD (Fig. 4b) were associated with a significant decrease in the root length and fresh and dry weights (Table 1) and an increase in the lignin content (Fig. 5). Whether or not this is true, it seems quite plausible to assume that naringenininduced inhibition in root growth of the soybean seedlings may be due to cell wall lignification induced by $\mathrm{H}_{2} \mathrm{O}_{2}$-dependent cell wall-bound POD. In simplest terms, the lignin monomers form a complex network that solidifies the plant cell wall and subsequently restricts root growth.

One may ask whether these effects are exclusively due to naringenin itself or due to products of its metabolism. Notwithstanding the fact that naringenin affects root growth, its uptake and metabolism has not been explored in soybean. An intriguing fact observed here was the increased level of $p$-hydroxybenzoic acid after naringenin treatments (Table 2). Degradation of flavanones in benzoic acid and their derivatives has been previously reported (Barz and Hoesel, 1979), and the non-enzymatic cleavage of naringenin produces $p$-hydroxybenzoic acid (Newhall and Ting, 1967). The potential of this phenolic compound to be allelopathic has been widely reported (Politycka, 1996; Doblinski et al., 2003; Inderjit and Duke, 2003; Weir et al., 2004). In agreement with this, enhanced quercetin autooxidation leads to the formation of the 3,4dihydroxybenzoic acid (Takahama and Hirota, 2000). At low concentrations, 3,4dihydroxybenzoic acid mimics auxin by 
stimulating callus formation, whereas at higher concentrations, this compound inhibits tobacco root growth (Mucciarelli et al., 2000). In addition, some flavonoid aglycones act to inhibit polar auxin transport, leading to a disturbance in normal auxin levels and resulting in the induction of lateral roots and the suppression of growth (Levizou et al., 2004). Thus, naringenin phytotoxicity may not occur only because of the ROS produced, but also due to the probable autooxidation forming the allelochemical $p$ hydroxybenzoic acid. This assumption, however, has still to be strengthened.

Deng et al. (2004) reported that the enzyme 4-CL has potential as a novel action site of plant growth suppression and, subsequently, as a site of plant growth retardation. This hypothesis cannot be supported from the available data reported here. On the contrary, the present study contained the experiments that supported the assumption that growth of soybean seedlings on naringenin led to an inhibition of root length followed by increased lignification. At least for soybean, the action site of naringenin may be related to other enzymes working at later steps of the phenylpropanoid pathway, such as cell wall-bound POD or, perhaps, cinnamyl alcohol dehydrogenase (CAD), a highly specific lignification marker. Therefore, the mode of action of naringenin remains an open question.

Finally, an important question in the area of allelopathy and in agricultural context is whether available concentrations of naringenin in soil are sufficient to inhibit the plant growth. However, there is no study evaluating allelopathic effects of naringenin in field's conditions. Thus, further study is necessary to strengthen the role of naringenin as an allelochemical.

\section{RESUMO}

Os efeitos de naringenina, um intermediário da biossíntese de flavonóides, foram avaliados sobre o crescimento das raízes, as atividades da fenilalanina amônia liase (PAL) e peroxidases, bem como sobre os teores de compostos fenólicos e de lignina em plântulas de soja (Glycine max L. Merrill). Plântulas de três dias foram cultivadas em solução nutritiva de Hoagland, meia-força $(\mathrm{pH}$ 6,0 ), contendo ou não, naringenina 0,1 a $0,4 \mathrm{mM}$, em uma câmara de germinação $\left(25^{\circ} \mathrm{C}\right.$, fotoperíodo de $12 \mathrm{~h}, 280 \mu \mathrm{mol} \mathrm{m} \mathrm{m}^{-2} \mathrm{~s}^{-1}$ ) durante $24 \mathrm{~h}$. Efeitos inibitórios no crescimento das raízes (comprimento, massa e viabilidade celular) e nas atividades da PAL e POD solúvel foram constatados após os tratamentos com naringenina. Estes efeitos foram associados com atividade estimulatória da POD ligada à parede celular, seguido por aumento nos teores de lignina, sugerindo que a inibição do crescimento das raízes pode ser devido ao processo de lignificação.

\section{REFERENCES}

Bais, H.P.; Vepachedu, R.; Gilroy S.; Callaway, R.M.; Vivanco, J.M. (2003), Allelopathy and exotic plant invasion: from molecules and genes to species interactions. Science, 301, 1377-1380.

Baker, C.J.; Mock, N.M. (1994), An improved method for monitoring cell death in cell suspension and leaf discs assays using Evans blue. Plant Cell Tissue and Organ Culture, 39, 7-12.

Barz, W, Hoesel, W. (1979), Metabolism and degradation of phenolic compounds in plants. InBiochemistry of Plant Phenolics. Recent advances in Phytochemistry, ed. T. Swain, J. B. Harbone, C. E. Van Sumere, Plenum Press, New York, pp. 339-367.

Boerjan, W.; Ralph J.; Baucher, M. (2003), Lignin biosynthesis. Annual Review of Plant Biology, 54, 519-546.

Brown, D.E.; Rashotte, A.M.; Murfhy, A.S.; Normanly, J.; Tague, B.W.; Peer, W.A.; Taiz, L.; Muday, G.K. (2001), Flavonoids act as negative regulators of auxin transport in vivo in Arabidopsis. Plant Physiology, 126, 524-535.

Cakmak, I.; Horst, W.J. (1991), Effect of aluminum on lipid peroxidation, superoxide dismutase, catalase, and peroxidase activities in root tips of soybean (Glycine max). Physiologia Plantarum, 83, 463-468.

Chen, W.; Yun, M.S.; Deng, F.; Yogo, Y. (2004), Effects of root-applied naringenin and chalcone on the growth of annual plants. Weed Biology and Management, 4, 118-122.

Colpas, F.T.; Ono, E.O.; Rodrigues, J.D.; Passos, J.R. S. (2003), Effects of some phenolic compounds on soybean seed germination and on seed-borne fungi. Braz. arch. biol. technol., 46, 155-161.

Deng, F.; Aoki, M.; Yogo, Y. (2004), Effect of naringenin on the growth and lignin biosynthesis of gramineous plants. Weed Biology and Management, 4, 49-55.

Doblinski, P.M.F.; Ferrarese, M.L.L.; Huber, D.A.; Scapim, C.A.; Braccinni, A.L.; Ferrarese-Filho, O. (2003), Peroxidase and lipid peroxidation of soybean roots in response to $p$-coumaric and $p$ hydroxybenzoic acids. Braz. arch. biol. technol., 46, 193-198. 
Ferrarese, M.L.L.; Rodrigues, J.D.; Ferrarese-Filho, O. (2000), Phenylalanine ammonia-lyase activity in soybean roots extract measured by reversed-phase high performance liquid chromatography. Plant Biology, 2, 152-153.

Ferrarese, M.L.L.; Zottis, A.; Ferrarese-Filho, O. (2002), Protein-free lignin quantification in soybean (Glycine max) roots. Biologia, 57, 541-543.

Herrig, V.; Ferrarese, M.L.L.; Suzuki, L.S.; Rodrigues, J.D.; Ferrarese-Filho, O. (2002), Peroxidase and phenylalanine ammonia-lyase activities, phenolic acid contents, and allelochemicals-inhibited root growth of soybean. Biological Research, 35, 59-66.

Inderjit; Duke S.O. (2003), Ecophysiological aspects of allelopathy. Planta, 217, 529-539.

Iwashima, T. (2003), Flavonoid function and activity to plants and other organisms. Biological Science Space, 17, 24-44.

Levizou, E.; Karageorgou, P.; Petropoulou, Y.; Grammatikopoulos, G.; Manetas, Y. (2004), Induction of ageotropic response in lettuce radicle growth by epicuticular flavonoid aglycons of Dittrichia viscose. Biologia Plantarum, 48, 305-307.

Macias, F.A. (1995), Allelopathy in the search for natural herbicide models. In-Allelopathy. Organisms, Processes, and Applications, ed. Inderjit, K. M. M. Dakshini, F. A. Einhellig, American Chemical Society, Washington, pp. 311-329.

Mucciarelli, M.; Scannerini, S.; Gallino, M.; Maffei, M. (2000), Effects of 3,4-dihydroxybenzoic acid on tobacco (Nicotiana tabacum L.) cultured in vitro growth regulation in callus and organ cultures. Plant Biosystems, 134, 185-192.

Newhall, W.F.; Ting, S.V. (1967), Degradation of hesperitin and naringenin to phloroglucinol. Journal of Agriculture and Food Science, 15, 776-1967.

Onyilagha, J.C.; Grotewold, E. (2004), The biology and structural distribution of surface flavonoids. Recent Research of Development Plant Science, 2, 1-19.

Passardi, F.; Cosio, C.; Penel, C.; Dunand, C. (2005), Peroxidases have more functions than a Swiss army knife. Plant Cell Reports, 24, 255-265.

Politycka, B. (1996), Peroxidase activity and lipid peroxidation in rests of cucumber seedlings influenced by derivatives of cinnamic and benzoic acids. Acta Physiologiae Plantarum, 18, 365-370.
Pourcel, L.; Routaboul, J.M. ; Cheynier, V. ; Lepiniec, L. ; Debeaujon, I. (2006), Flavonoid oxidation in plants: from biochemical properties to physiological functions. Trends in Plant Science, 2, 29-36.

Ramakrshina, M.B.V.; Mital, B.K.; Gupta, K.C.; Sand, A.N. (1989), Determiantion of phenolic acids in different soybeans varieties by reversed phase high performance liquid chromatography. Journal of Food Science and Technology, 26, 154-155.

Rice-Evans, C.; Miller, N.J.; Paganga, G. (1997), Antioxidant properties of phenolic compounds. Trends in Plant Science, 2, 152-159.

Sánchez, M.; Peña, M. J.; Revilla, G.; Zarra, I. (1996), Changes in dehydrodiferulic acids and peroxidase activity against ferulic acid associated with cell walls during growth of Pinus pinaster hypocotyl. Plant Physiology, 111, 941-946.

Santos, W.D.; Ferrarese, M.L.L.; Finger, A.; Teixeira, A.C.N.; Ferrarese-Filho, O. (2004), Lignification and related enzymes in Glycine max root growthinhibition by ferulic acid. Journal of Chemical Ecology, 30, 1199-1208.

Sarma, A.D.; Sharma, R. (1999), Purification and characterization of UV-B induced phenylalanine ammonia-lyase from rice seedlings. Phytochemistry, 50, 729-739.

Takahama, U.; Hirota, S. (2000), Deglucosilation of quercetin glucosides to the aglycone and formation of antifungal agents by peroxidase-dependent oxidation of quercentin on browing of onion scales. Plant Cell and Physiology, 41, 102-1029.

Takahashi, L.; Sert, M.A.; Kelmer-Bracht, A.M.; Bracht, A.; Ishii-Iwamoto, E.L. (1998), Effects of rutin and quercetin on mitochondrial metabolism and on ATP levels in germinating tissues of Glycine max. Plant Physiology and Biochemistry, 36, 495-501.

Taylor, L.P.; Grotewold, E. (2005), Flavonoids as developmental regulators. Current Opinion in Plant Biology, 8, 317-323.

Veitch, N.C. (2004), Horseradish peroxidase: a modern view of a classic enzyme. Phytochemistry, 65, 249259.

Weir, T.L.; Park, S.W.; Vivanco, J.M. (2004), Biochemical and physiological mechanisms mediated by allelochemicals. Current Opinion in Plant Biology, 7, 472-479. 